\title{
On the Fringe
}

\section{Sheepdogs and Their Status Within Bronze Age Ontologies in Scandinavia}

\section{Kristin Armstrong Oma}

This contribution draws mainly on images of dogs, humans and sheep from Nordic Bronze Age rock art sources, but living arrangements within the household and depositional patterns of $\mathrm{dog}$ bones on settlements are also considered to extrapolate an understanding of the physical reality and ontological role of sheepdogs within the social aspects of the practice of herding. I use theories from the interdisciplinary field of human-animal studies to understand how socialisation, habituation and trust create a seamless choreography between human, dog and sheep.

Keywords: human-animal relations, second millenium, sheep, herding

This is an Open Access article distributed under the terms of the Creative Commons 4.0 International licence (CC BY 4.0) (http://creativecommons.org/licenses/by/4.0/), which permits unrestricted use, distribution, and reproduction in any medium, provided the original work is properly cited. 


\section{From human-animal to interspecies relationships}

What do we mean when we use the term 'animal' when talking about human-animal relationships? I have struggled with breaking up the 'animal' category, that at times leaves little room for understanding the different species, their particular potential, abilities, specificities, interrelationships and interdependencies, as well as the ontological status of each being. Researching herding - sheep, dogs and shepherds - in the early Bronze Age allowed me to conceptualise the different kinds of beings as players on the same field. Looking at the dynamics among these kinds of beings, the 'animal' category began to disintegrate. The research process was in part guided by my own experience of working with and training Border Collies. This contribution springs from eureka moments from my own work as a dog handler and outlines some of this work in conjunction with my archaeological research and forays into ethological research. Traditionally, scientists have looked at animals as objects - simply because that is what they are trained to do - and archaeology has followed this lead. Researchers have striven for objectivity - 'a view from nowhere' (Nagel 1986). My choice to bring my own experiences into my academic work is a feminist project of making my standpoint as a researcher transparent, and is in line with how Sandra Harding (1986) and Donna Haraway (I988) have uncloaked the normative academic voice that strives for objectivity as a 'view from nowhere' and a 'god-trick.' Everybody has a view from somewhere, embedded in the zeitgeist of their time, and socio-cultural biases are always and everywhere present in our work. As academics, we are stakeholders within paradigms and we do research on subjects and questions we are passionate about and personally drawn towards.

In the herding situation, sheepdogs are their own agents, they engage in a social world and are responsible for performing tasks from the position of individual, autonomous problem solving. Indeed, the shepherds draw upon capacities that are inherent in good sheepdogs when they train the dogs. In sheepdogs, the original hunting instincts have been harnessed and moulded to herd and protect (Westling 20I4). A good sheepdog handler will socialise the dog to be a free agent, and even though the cognitive scaffolding of commands and communication are important in training (Keil 20I5), the most important factor is the development of trust and intuitive understanding between human, dog and sheep (Scrimgeour 2002). In this contribution I will discuss the fringe position of herding dogs, and the specific kind of hybridity that working interspecies relationships entail. When more than one kind of agent are working together, a key aspect to their success is early socialisation and habituation to each other as different kinds of beings. The types of agents need to grow into being together. 
I am inspired by Ann Game (200I) and her article Riding: Embodying the Centaur, in which she outlines her own experience of becoming together with horses. This is described as an experience of intense embodiment, where the horse and the rider are so in sync it feels metaphysical. Game describes this as a kind of hybridity, in which the rider experiences oneself as a hybrid being, that is sometimes glimpsed in prehistoric art (e.g. Kristoffersen 1995; Ahlqvist \& Vandkilde 20I8). It serves as an example of the usefulness of an exploration of the human-animal interface at an anecdotal level.

However, the hybridity explored by Game and others (e.g. Argent 20I 2; Haraway 2008; Hearne 1987) is not ubiquitously applicable to human-animal relationships. Unless we consider species specificities, and examine the animals as themselves, the animal frequently slides into a generic category, and rather than considering relationships involving specific humans and nonhumans, a catch-all human-generic animal relationality is envisaged. In such a setup, humans and their relationships with single species are imagined. But in herding, the three kinds of beings represent different kinds of engagements and different spatio-temporal trajectories. From this perspective, the hybridity experienced and theorised by Game (200I) in her mutual becoming with her horse is not directly comparable to the mutual becomings experienced by the triad of humans, sheep and sheepdogs in herding.

Herding is an example of a working relationship between humans and non-human others, and such relationships allow humans 'to engage the world in ways beyond their individual and human capabilities', and in these engagements humans and non-humans both 'enter into reciprocally affecting relationships with shared and co-determined trajectories that enable both animals to inhabit new spaces together' (Keil 2015:509; see also Haraway 2008; Kirksey \& Helmreich 2010).

In this article my aim is to explore the status of sheepdogs in the herding triad in Bronze Age Scandinavia and what this status entails in practice. To do this, I investigate the physical evidence of dogs from different Scandinavian contexts, by drawing together osteological evidence, its depositional context and the treatment of the faunal remains, and rock art that portrays dogs and herding scenes. Human-animal studies (see for example Bekoff 2002; Cudworth 20II; DeMello 20I2) combined with a practice perspective informs my archaeological research on human-animal relationships and my focus is on ways to approach the lives of past animals, rather than their deaths. How would particular human-animal practices be manifested in material culture and spatial set-ups? Clearly, different kinds of animals would contribute in different ways to joint practices, and the humans, sheep and dogs would have to respond to each other's behavioural patterns and agency and through their responses, mutually become the action of herding. 


\section{Dogs in the Bronze Age}

I have chosen to focus on sheepdogs because in herding, they occupy a fringe position as mediators - neither fully animal nor human - and this serves as a starting point to explore their potential status as hybrid beings. Archaeologically, in Bronze Age Scandinavia (circa 2000/I800-500 BCE), this fringe position is discernible by way of the depositional patterns found at some well-preserved archaeological sites, as well as by analysis of rock art motifs (see Figure I for an overview of sites). First, I turn to the faunal remains and their contextual patterns. The osteological evidence of dogs testifies to size, which indicates breed and abilities; the treatment of the bones as well as their manner of deposition are indicative of their status in society. In Scandinavia, faunal remains from dogs are not very common, but are found at some sites with good preservation. In Norway, the acidity of the soil prevents good bone preservation, and hardly any dog bones have been retrieved from the Bronze Age, but there are several sites in Sweden and Denmark with dog remains. Common to Scandinavian Bronze Age sites are dog bones in domestic deposits in, for the main part, Late Bronze Age (circa I I00-500 BCE) houses and pits in settlements, which rarely show any sign of having been butchered or eaten (Nyegaard 1996:49-53; Ullén I996:153). A comparative study of dogs in Bronze Age Europe concludes that they were mostly medium to large, thought to have been either companions, watch dogs, or hunting dogs (Benecke I994) - and, I would add, herding dogs.

Due to exceptional osteological preservation, the most informative site regarding the status of Bronze Age dogs in Scandinavia to date is Apalle in Sweden (Ullén 1994, 1995a, 1995b, 1996, 1997a, 1997b), and it is therefore worth closer consideration here. The site represents the remains of a settlement that spanned the Early and Late Bronze Age. The presence of dogs and their changing status can be traced by way of depositional practices. Due to stellar preservation, unusually high numbers of bones were found in situ. Dog bones comprised I.3\% of all the bones identified, and were morphologically classified as representing a spitz type, a breed which is frequently used for herding (Ullén I996:I50). Dog bones were found at the site from both the Early and Late Bronze Age phases, and in both periods, dogs were clearly non-food, as there is no evidence of butchery or cooking on their bones (Ullén I996:I53). Faunal remains from other domestic species - sheep, cattle and pigs - were found in pits scattered across the settlements; the bones have heavy butchery marks and were clearly the remains of meals, but incidentally, horse remains were treated similarly to the dog remains (Ullén I996).

A particular depositional pattern is seen in the Early Bronze Age phase of the settlement: dog bones were deposited with care in pits with fire- 


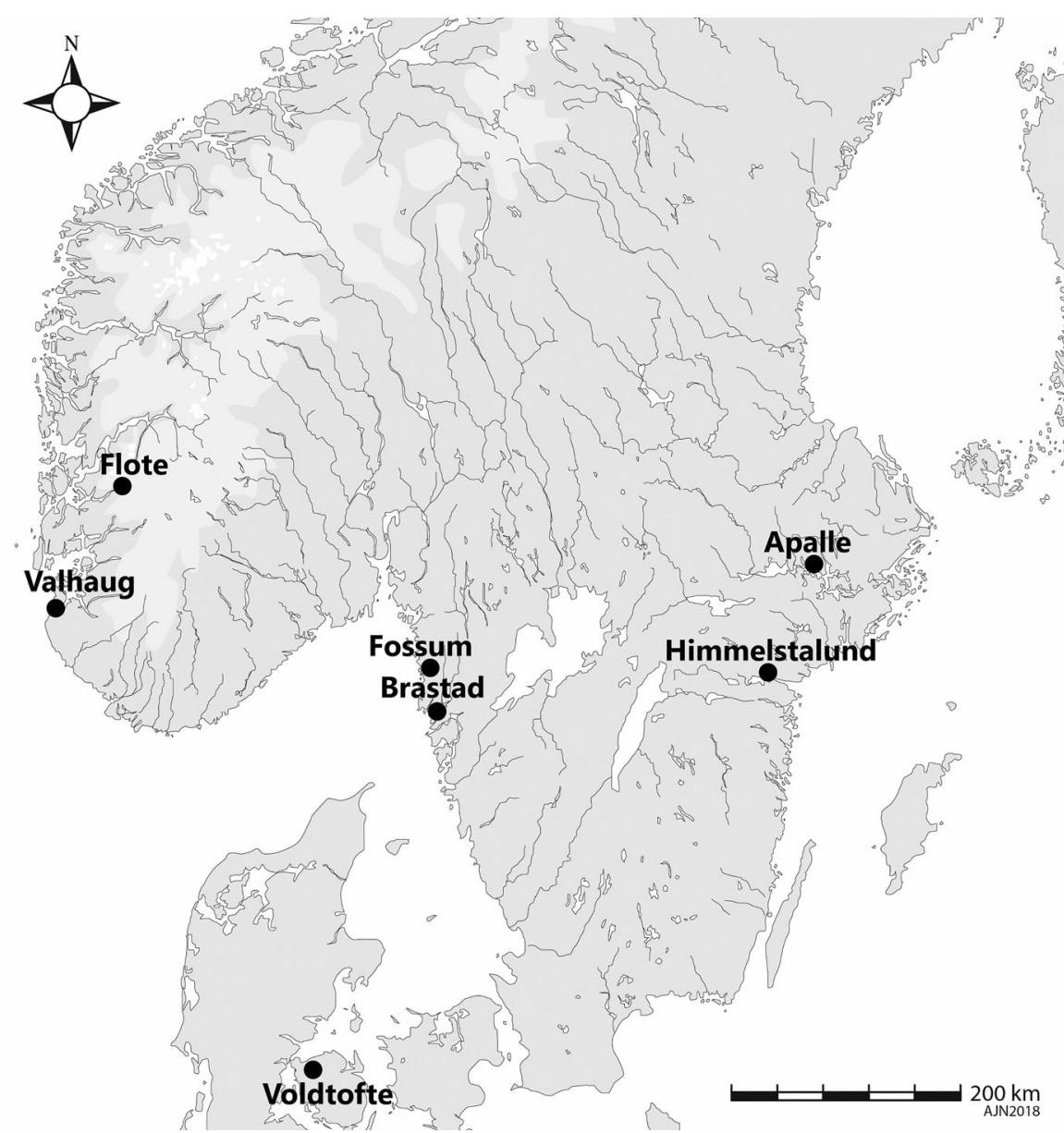

Figure I. Map of southern Scandinavia with sites mentioned in the text. Map by Astrid Johanne Nyland.

cracked stones at the 'outermost boundary of settlement' (Ullén I996:150). In addition to these special deposits, fragments of dog bones also occur widely. In the Late Bronze Age phase (Ullén I996:I5I) these 'dog pits' were found near houses, often one near each house, either by the end wall or near the entrance. There was always a cranium in the pit, giving them a 'grave-like character, with dogs being deposited individually or in pairs' (Ullén 1996:I5I). Ullén (1996:I53) also reports houses in which dog jaws were buried in pits underneath the clay floor or in postholes on either side of the house entrance. (Ullén I994, 1996, I997b:67). Based upon this depositional pattern, a close relationship between humans and dogs is presumed (Ullén 1994, 1996, 1997b). Notably, the initial placing of the dog pits at the fringes of the Early Bronze Age settlement may indicate that the dogs 
defined the boundary of the settlement, the threshold between inside and outside. Following this line of reasoning, in the later phases of the settlement, the positioning of dog pits near the houses could indicate that dogs defined and confined the domestic space of each household. The development could be from dogs guarding or herding the edges and thus enclosing the members of the settlement, to guarding or herding the members of each household. Further, this could indicate a movement from a more communal association to a more personal, individual relationship. The function of the dogs may have shifted from guarding the community at large to guarding the household.

In Denmark only small bone assemblages have been recovered from Early Bronze Age sites, with a few larger assemblages from the Late Bronze Age (Nyegaard 1996). For example, only a single dog tooth was retrieved from the Early Bronze Age site of Torslev. Indirect evidence of the presence of dogs was found at other sites, such as Bjerre, where cattle bones had gnaw marks. Most notable from the Late Bronze Age are the middens from Kirkebjerget, Voldtofte, where high numbers of dog bones are present (Nyegaard 1996:49-54). Similar to Apalle, the dog bones were deposited separately in pits, and not amongst other bones in the cultural layers. Most of the bones are intact. The dogs ranged from young to old, and their sizes indicate that they were large (about the size of a modern German shepherd, or even larger). Cut marks indicate that some dogs had their heads cut off or were butchered. Gnaw marks on $5.8 \%$ of the bones of other species also attest to the presence of living dogs on site.

The fact that the dog bones are so scant in general on Scandinavian Bronze Age sites points to a dietary taboo - dogs were not eaten. This, at least, is the conclusion drawn by Gräslund (2004:I67), since she notes that dog (and horse) bones are hardly ever found at settlement sites, but are abundant in wetland sacrifices. For example, at the sacrificial site of Östra Vemmerlöv in Scania, dogs accounted for by far the largest number of individuals (van Post I9I9). Ullén (I996:I46) states that altogether there are 20 human graves with dogs in Bronze Age Sweden, mainly from Early Bronze Age period II-III (I500-I IO० BCE). Both the depositional patterns and the graves attest to the special role dogs held in Bronze Age society. On the basis of this, Ullén suggests that a close relationship between dogs and humans existed in the Bronze Age (I996:I60), but she does not explore what this postulated proximity implied. Georg Nyegaard (1996:49-54) is more pragmatic and suggests that the dogs were probably working animals, assisting shepherds, since the large size of the dogs found on Danish sites would be suitable for shepherding large flocks. This is in line with Miklósi's (2015:73) statement that 'using dogs to herd large groups of sheep or cows saves a great deal of human effort'. 
The evidence from the dog pits at Apalle, the treatment and deposition of dog bones from Danish sites as well as the dogs in graves and wetland sacrifices in Sweden testify to dogs having a relationship with humans that was significantly different to that of other domestic animals (horses excluded). The notion of the dog as 'man's best friend' is easily invoked, but this is a modern idea and I believe it should not be directly imposed upon the societies of prehistory without considering subsistence strategies, lifeways and religious underpinnings. Also, the lesson of human-animal studies is that animals should be considered as themselves, with the particular ramifications that they each bring to relationships with humans. Rock art gives more specific pointers towards the nature of this relationship, and in the following I will expand upon the nature of human-dog relationships by investigating Scandinavian Bronze Age rock art motifs.

\section{Species specificities: dogs in rock art}

Dogs are distinctive (although not unique) in that they are able to bond with humans from birth and accept humans as primary caregivers (Bradshaw 20II). The biological window of opportunity in which they accept individuals from other species as their secondary caregivers is I6 weeks (Appleby et al. 2002; Bradshaw 20II). This means that they have an exceptional capacity for socialising and forming deep bonds with individuals of other species. Further, they can form such bonds without losing their sexual orientation towards their own species. This means that dogs can imprint on humans but will still choose to mate with their own species. This biological ability means that dogs are exceptionally well suited to bond deeply with humans while still successfully reproducing. They effectively retain simultaneous membership in different flocks. This must have been a trait that dogs developed early on, possibly as a result of co-domestication with humans: humans and dogs developed behavioural traits in tandem, finely tuned to each other (Bradshaw 20II).

Dogs, then, have the capacity to form deep and trusting bonds with their human partners, accounting for the special relationships between humans and dogs that have been documented throughout history. In the Scandinavian Bronze Age, such relationships can be glimpsed on rock art depicting humans and dogs together as well as herding scenes with humans, dogs and sheep. Rock art with animal scenes can normally not be dated to specific periods of the Bronze Age, therefore a broad Bronze Age date is given for the motifs discussed below.

Rock art motifs that portray dogs attest to close observation and intimate knowledge of dogs as individual animals. As such, there are two as- 


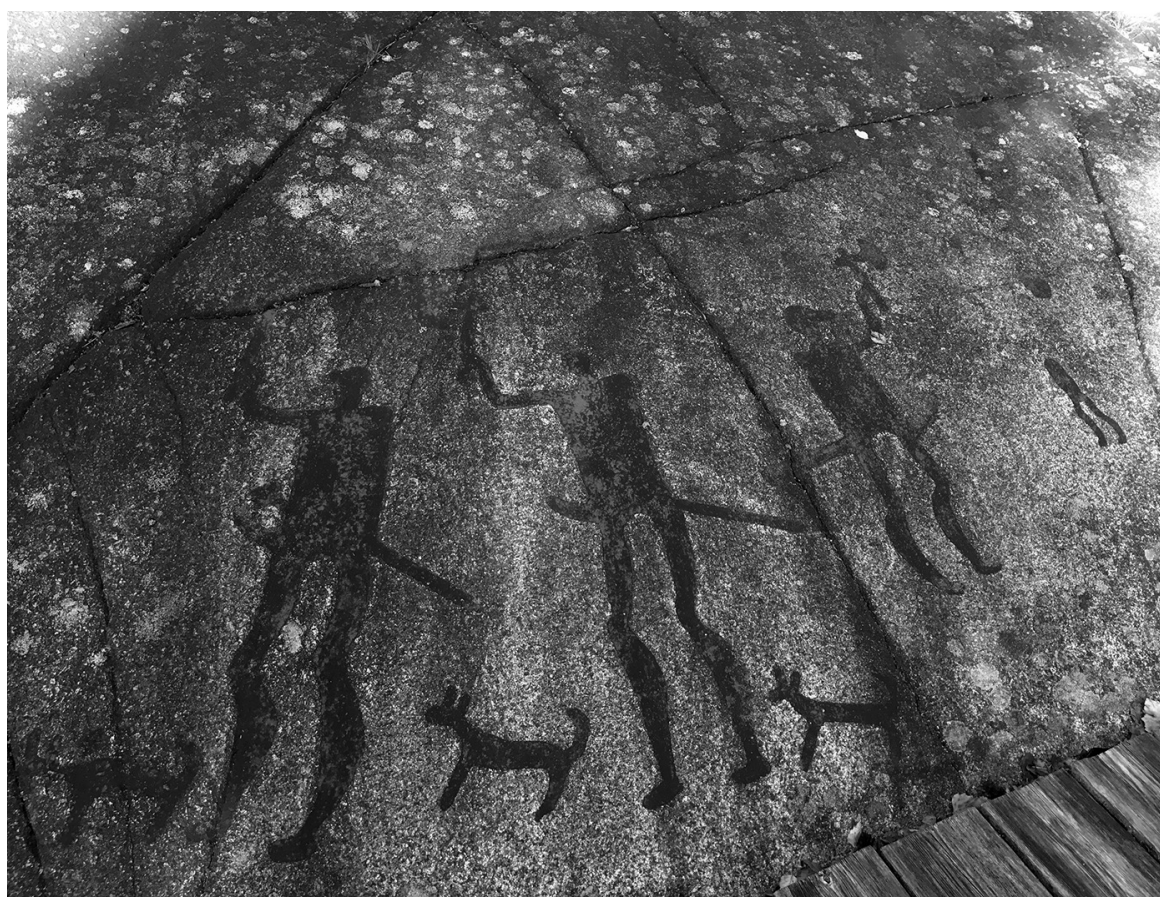

Figure 2. Fossum in Tanum, Sweden, panel with dogs and humans. Photo by author.

pects to rock art: one is that the rock carvers presumably portrayed the world around them, what they observed and knew. From this perspective, rock art is peopled by many kinds of beings. The other aspect of rock art goes beyond the individual; dogs also partake in the universe created on the rocks, which is perceived as loaded with mythological significance (e.g. Goldhahn 2006; Goldhahn et al. ed. 20I0). Depicting dogs - and moreover a herding scene - in the cosmological sphere of rock carvings goes some way towards merging lived human-animal relationships and the choreography of herding with the realm of the otherworld. This adds both depth and a glimpse of different dimensions to be found in the images. However, the main focus here is on the unintended portrayal of beings - especially dogs - in a manner that discloses the role dogs had in society.

A salient example of the portrayal of humans and dogs is the site of Fossum in Tanum, Sweden (Figure 2). Here, humans brandishing phalluses and axes and carrying swords are depicted with dogs with upright ears and tails. Humans and dogs both give the impression of imminent action, of being alert and ready to strike. The stance and body pose of the dogs accentuate the impression of heightened awareness, of being ready to attack. Anne-Sofie Gräslund (2004:I67) suggests that 'With their erect ears, curled tails, and steep angulation of both forequarters and hind quarters they are similar to 

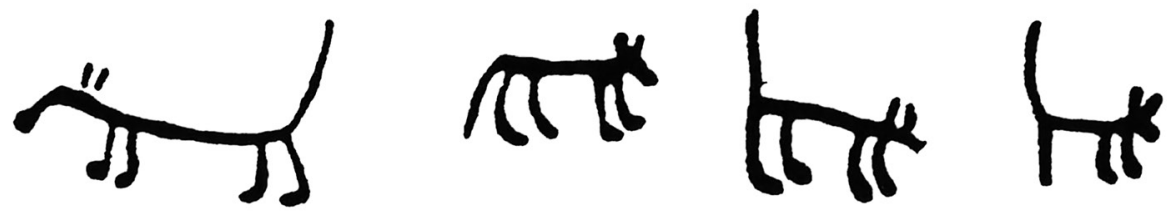

Figure 3. Dogs from Flote I, Norway. By permission of Kjersti Vevatne (I996:26).

spitz dogs' (see also von Rosen 1954). Gräslund further notes that several of the rock art scenes with dogs appear to depict hunting, but this particular one gives, in her opinion, the impression of a ritual performance or ceremony. However, my reading of this scene goes beyond pinpointing the exact nature of the activity that the humans and dogs engage in. What I find noteworthy is the positioning of humans and dogs and their stances: the proximity between the dogs and the humans, how the dogs are positioned by the feet of the humans, how they are moving in the same direction, and how the dogs and the humans mirror each other's alertness. The scene lends itself easily to interpretation as performative action, as suggested by Gräslund. Just as significant is the way humans and dogs seem to act as one. The scene displays a directionality and purpose and the two kinds of beings - dogs and humans - mirror each other in such a way as to accentuate the drive underlying the scene. The rock art suggests that in Bronze Age societies dogs and humans formed deep bonds much like those described in contemporary biological studies of human-animal relationships (Bradshaw 20II).

The Fossum panel is not unique in rendering scenes that depict humans and dogs. Often, these are hunting scenes (e.g. Bertilsson 1994:95, II 8; Fredsjö I969:I I5, II7, I28). The artistic execution of the dogs ranges from vague canine shapes to more specific renderings that are indicative of breed. Most of the dogs resemble the spitz-like breed seen at Fossum. This is also true for the apparent dogs in four carvings at the Bronze Age rock art panel of Flote I in Etne in Western Norway (Figure 3). All of the dogs have paws, three are depicted with upstanding tails and one has a hanging tail (Vevatne 1996:26-27). These dogs also look like spitz dogs and bear a great likeness to the contemporary Norwegian herding breed Buhund, with their alert stance which is indicated by their curved upright tails and ears. Buhund literally means 'dog in the dwelling'. $B u$ - refers to farm, farm animals or settlement, and hund means dog. The Buhund is believed to be the descendant of the dogs of the pioneer settlers of early Mesolithic Norway and is an all-around farm dog used for herding and as a watch-dog (Thorsen 200I:I06). Archaeological evidence has established that dogs morphologically very similar to the Buhund were present in Scandinavia in the Iron Age (Lia 200I), demonstrating that the breed has deep roots. Two dogs with a similar pose to the distinctive Buhund stance are also seen on a 


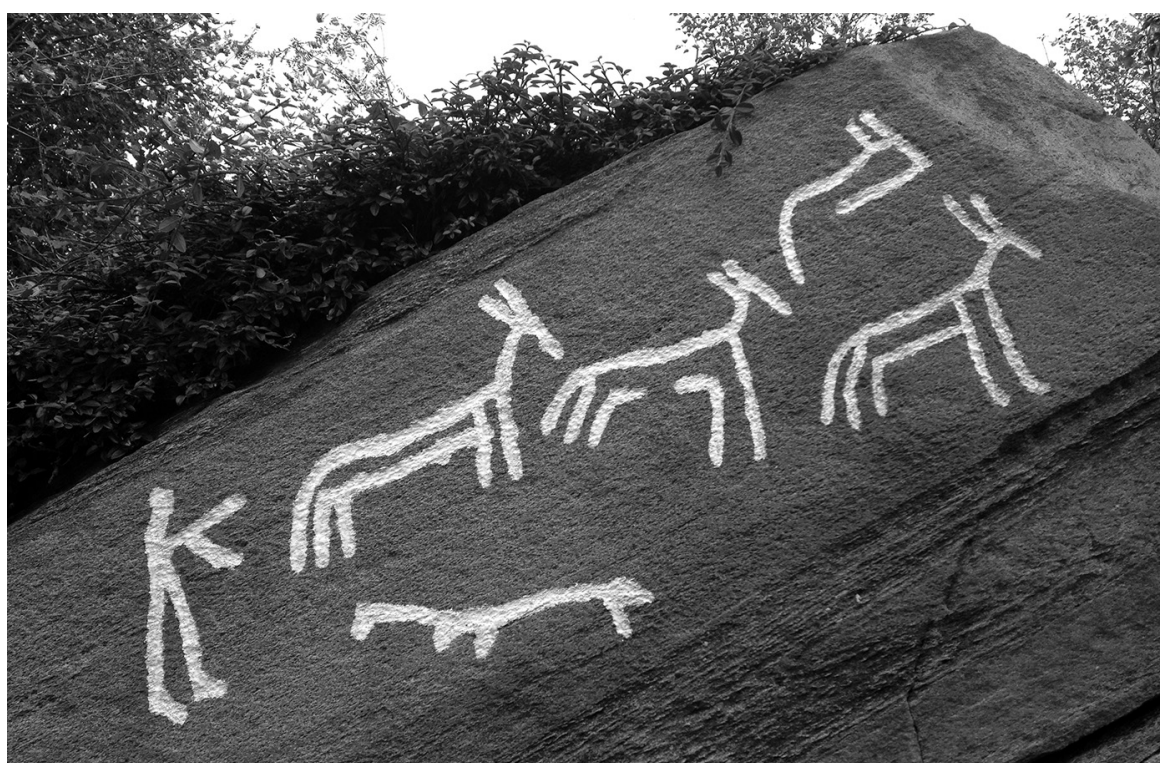

Figure 4. The herding scene from Valhaug, Norway. Photo by author.

Bronze Age rock carving from Hamn Kville in Bohuslän (Fredsjö I969:I I7, bild 43). Here, two dogs form dyads with their respective humans as they stand between two archers, pairs of men and dogs face and oppose each other in a manner that could be interpreted as hostile.

In contrast, a dog on a Bronze Age rock art panel at Valhaug on Jæren in southwestern Norway that seems to engage in sheep-herding keeps the tail low, suggesting intense concentration (Figure 4). A panel from Himmelstalund Östra Eneby in Norrköping probably also portrays herding, although possibly of pigs rather than sheep (Figure 5). A human figure and a dog are placed behind a flock of animals, and another human figure is placed amongst them. The dog's tail is low and s/he is aligned with the shepherd (or pigherd). A third panel, from Brastad I24:I, is also interpreted as shepherding (Toreld \& Andersson 20I7:54-55, I4I; Figure 6). The shepherd is brandishing a crook or a staff in front of her/him, and seems to have a sword fastened to her/his back. Right in front of her/him on either side are two animal figures, interpreted as herding dogs. Their ears are alert and their tails are flat and away from the body. One of them clearly has his mouth open, probably to indicate barking (Anders Toreld, pers. comm. 20I7). The two seem to be a team, by their positioning, on either side of the shepherd. The dogs and the shepherd drive a herd of four animals, all moving in the same direction with a forward dynamic.

The different ways that dogs are portrayed in these scenes indicate that the rock carvers paid acute attention to the dogs' breed, personality and 


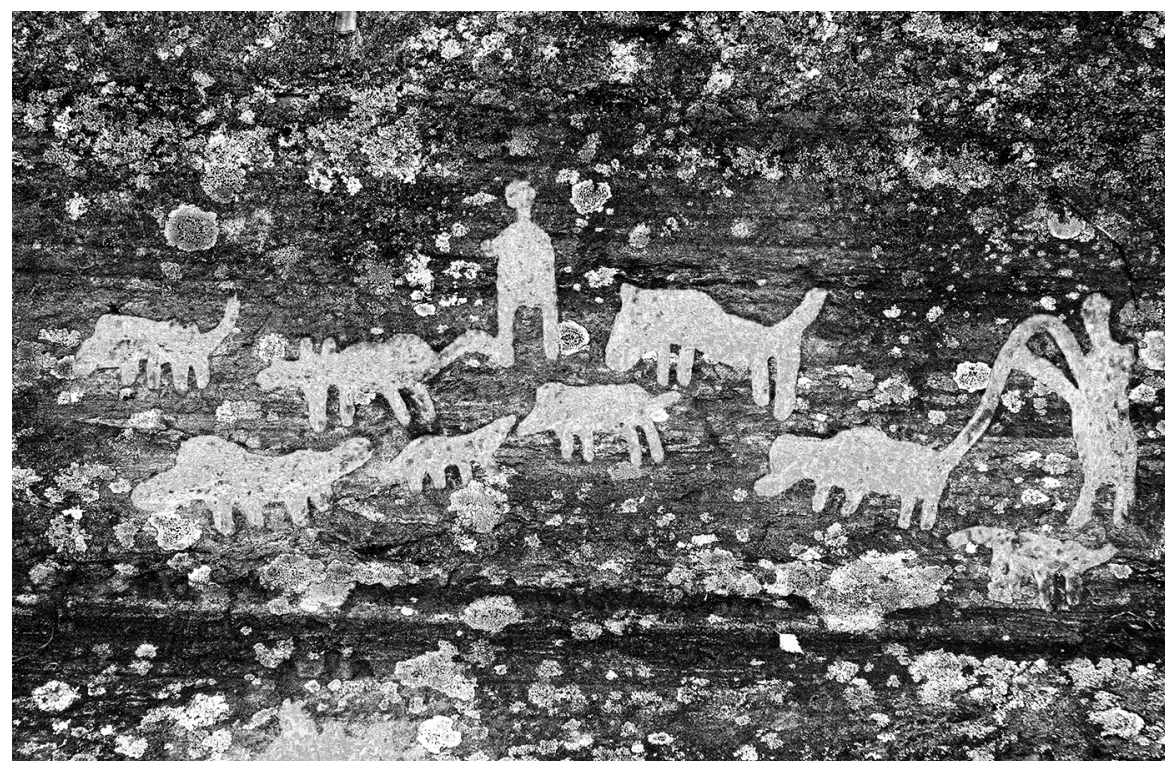

Figure 5. The panel from Östra Eneby I Himmelstalund in Norrköping depicts a flock of seven animals herded by two humans, one carrying a shepherd's crook, and a herding dog at the back next to the shepherd. Photo by Catarina Bertilsson, Swedish Rock Art Research Archives, ID: SHFA_idgro9.

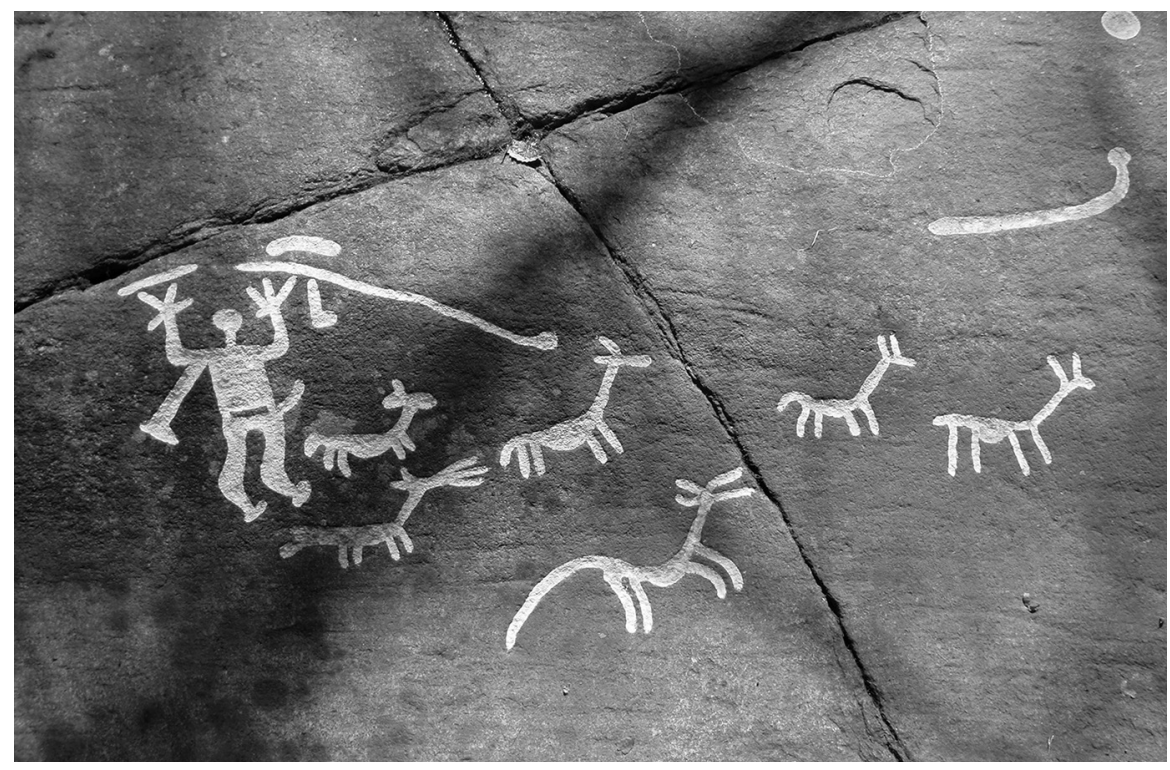

Figure 6. Herding scene from Brastad, Lysekil. A man carries a sword and holds a shepherd's crook. Close by are two dogs, one with an open mouth. The dogs and shepherd herd a flock of four animals. By permission of the Stiftelsen för dokumentation av Bohusläns hällristningar, ID: Brastad I24_I detalj2.jpg. 
situation. Spitz dogs are herding dogs, and the Buhund is still in use as a herding dog in Norway, although the Border Collie is the most common sheep herding dog.

The rock art panel at Valhaug deserves in-depth discussion. The motif is unique in its clarity - although a few other herding scenes with humans, dogs and sheep are found in Sweden (for example at Brastad and Himmelstalund Östra Eneby), nothing similar to the distinctive rendering of this scene is found in Scandinavian rock art. A little herd of four horned animals moves as one towards the right. To the left, behind the herd, is a shepherd with arms outstretched who drives the herd forwards. Moving in the opposite direction of the flock and effectively encircling it is a crouching dog, with tail held low. The dog and the outstretched right arm of the shepherd are carved to align with each other. Although the shepherd's arm and the dog do not meet, they form a barrier against straying sheep, and together shepherd and dog appear to work as one. The human-dog dyad cannot, however, be separated from the herd and the act of herding. The energy in the scene is clearly directed and controlled by the shepherd and the dog who choreograph the forward movement of the herd. The scene bears a striking likeness to how sheep herding with dogs is performed today.

\section{Herding dogs as hybrid creatures}

In the following, I will explore herding as an interspecies performative act that involves shepherd, sheep and sheepdog and some implications of herding both for Bronze Age societies and for the archaeology of human-animal relationships. Although it is not known for certain what types of dogs were present in Nordic Bronze Age societies, by way of the rock art we know that dogs were significant participants in several kinds of situations. Judging by the Valhaug and Brastad motifs, I suggest that some dogs were sheepdogs, and are even portrayed working in a way that bears an uncanny likeness to the working style of modern sheepdogs, in particular Border Collies.

Rock art scenes that depict herding introduce greater complexity to human-dog relationships by incorporating another species into the mix: sheep. Humans, sheep and dogs work in tandem across species boundaries. These scenes are unique in the way they allow for a conceptualisation of different kinds of beings as players on the same field. Investigating the dynamics among these kinds of beings causes the animal category to begin to disintegrate.

In herding, there are three kinds of being, and the particularities of the situation demand that these three together inhabit new spaces. The human shepherd is the mastermind - the one who creates the set-up. Paul Keil 
describes sheepdog trials, competitive and performative displays of shepherding, as an interspecies distributed cognitive system, where the handler (human) provides cognitive scaffolding for the dogs - aids them through an obstacle course by way of fine-tuned audible signals. The flock of sheep are the ones being herded, by category animal others. But where does this leave sheepdogs? As the ones that move the sheep they are guided by the handler's cognitive scaffold (Keil 20I5), simultaneously engaging with independence and free will. As such, they act as an intermediary between the shepherd and the sheep. Sheepdogs embody several roles: they are animals, but hyper-social ones that are exceptionally skilled at coordinating their actions with humans (Miklósi et al. 2003); they are experts at reading human body language and adjusting their own behaviour to work in complete obedience; and they simultaneously work independently to solve complex tasks (e.g. Westling 20I4). They are necessary tools and companions to the shepherd. Sheepdogs are therefore in a double sense beings on the fringe, both categorically and in practice.

In the herding situation, sheepdogs engage in a social world in which they perform tasks as autonomous, problem-solving individuals but in cooperation with other species, and such interspecies relationships entangle humans and animals in complex and co-affecting ways (Kirksey \& Helmreich 20I0). However, such cooperation does not arise out of nowhere. When more than one kind of agent are working together, a key aspect of their success is early socialisation and habituation to each other as different kinds of beings. Socialisation entails that different types of agents need to grow into being together (Armstrong Oma 2018a).

Dogs that are trained to herd other animals need to master several complex cognitive skill sets. They must be trained to communicate with their human handler, socialised with the animals they herd, and able to make decisions independently of the handler when the situation requires it (Sykes I999; Scrimgeour 2002; Price 2009; Westling 20I4; Keil 2015). Handler, dog and sheep form a triad dependent upon knowing and communicating with each other in order to make herding work.

Louise Westling (20I4) is informed by semiotics in her discussion of the zoosemiotics of herding sheep with dogs, and how to train herding dogs. She underlines how important it is that the dogs 'agree to cooperate in this game or dance, and the trainer must earn that agreement [...] The human trainer must 'read' the dog's behaviour, just as the dog must attend to and 'read' the trainer's behaviour' (Westling 20I4:44). She leans on Deleuze and Guattari (2004[1987]:262-263) and their idea of 'becoming-animal', in which humans become animals and animals become humans 'by moving in a block of synergy and thinking with the other' (Westling 20I4:44). She goes on to say that adding sheep to dog training brings great complex- 
ity into the block of becoming, because the three species are all involved in bodily communication that leads to cooperation.

The sheep need to be 'dogged', meaning that the sheep will learn to seek each other and form a herd when a dog approaches (see Pryor 2006 [1998]:98; Westling 20I4:49). This process is a habituation and socialisation process between sheep and dog in which their natural instincts - for sheep to flock, and for dogs to hunt - are moulded to create herding. It requires more moulding and training for the dog than it does for sheep. An ethnographic study from Rogaland of sheep and transhumance to mountain pastures quotes shepherds who claim the same thing: sheep need to be familiar with dogs in order to respond to herding as a choreography, otherwise they will scatter to all the furthest and most inaccessible corners of the mountain and chaos will ensue (Grimstvedt et al. 1996:196-197).

Therefore, an in-depth discussion of the making of a sheepdog is appropriate, since this would have been a major challenge for the Bronze Age shepherd. The dog in the Valhaug scene is in a pose that is strikingly similar to how modern Border Collies work sheep.

Border Collies have been bred for their working skills rather than according to a breed standard of physical appearance, which has secured the favourable traits that make them so suitable for herding. However, the breed cannot claim pedigree back to the Roman Empire; it was only registered in I9I5. Nonetheless, dogs that look like Border Collies are found on works of art that go far back in time. And since sheep herding has great time depth, going back to the secondary products revolution and beyond, sheepdogs presumably have great time depth too. The name of the breed is less relevant than the qualities of the breed, and what kinds of tasks can be accomplished with those qualities. The Border Collie is interesting because in these dogs, such qualities are not only extremely well developed but also well documented. The working style of this breed, with their low pose - crouching, almost, and coming around the flock at the back, is the strategy employed by the sheepdog on the Valhaug panel. This is typical herding behaviour, and efficient in both rounding up and driving sheep. The dogs creep along the ground, behind the sheep, weaving back and forth to gather up any stragglers. In addition to the remarkable intelligence of Border Collies, they are also extremely energetic, acrobatic, athletic and agile. These qualities make the breed highly suitable for sheep herding, as intelligence, agility and physical stamina are required for long days of work, often in difficult weather and challenging terrain. The shepherd might be too far away to see, or to signal, and the dog must solve problems by her/himself, such as guiding sheep off dangerous cliff ledges (Kennard 2004, 2005; Longton \& Sykes I997; Scrimgeour 2002; Sykes 1999).

In order to communicate with the handler, the dog and human must know each other and together learn commands (a process known as en- 
training; Game 200I) with spatial-temporal ramifications. Sheep-herding includes commands for outrun, left and right, and requires the dog to position her/himself in proper relation to the handler at all times (Scrimgeour 2002). However, in some landscapes, such as those found in Norway, the sheep will have wandered off to places that are inaccessible to humans and the human shepherd needs to put her trust in the $\operatorname{dog}(\mathrm{s})$, and their individual problem-solving skills (Grimstvedt et al. I996). Inherently, shepherds not only grant sheepdogs agency and full use of complex mental faculties, but also observe the dog's real life execution of split-second planning and decision making that require, amongst other things, complex understanding of the behavioural patterns of individuals of other species.

The history of the Border Collie serves well as a parallel for the development of sheepdogs in the Bronze Age, since the qualities that today are prevalent have been nurtured consistently for just over a century. The development of Border Collies as a breed owes much to the dedication and commitment of the shepherds who cared enough to breed only the best; without them and their knowledge the Border Collie as we know it today would not exist (Sykes 20I4). A similar scenario can be imagined for the Bronze Age: the intensification of keeping sheep and the need to herd larger flocks, in a changing landscape, led to seeking out new qualities in the dogs that worked the sheep. These might have included a gentle manner, a strong eye, a wide outrun - ways of working that allow the sheep to deal with the stress of herding. Above all else, the ability to work in close coordination with the shepherd would be vital, and the rock art from Valhaug attests to a close working relationship. As the need arose, with the onset of intensified sheep husbandry, such qualities could be nurtured and brought to fruition within a few generations of dogs. Thus, it could be that dogs such as the first famous trialing champion, Border Collie Old Hemp, have forebears in ancient times in the deep history of shepherding, flashing meteors that we will never know.

The Buhund has a different working style compared to Border Collies. They have a stronger chase-instinct and drive the flock away from the shepherd rather than rounding up. Additionally, they bark - they do not work silently. These characteristics are suitable for gathering up large flocks from mountain pasture, but less so for closer interactions on the farm (Grimstvedt et al. I996:196-I97).

The working styles of both of these herding breeds, Border Collie and Buhund, seem to be portrayed on rock art. The carving from Brastad is more reminiscent of herding by barking, similar to the Buhund style. The Valhaug scene strongly resonates with the current style favoured by Border Collies. Thus, more than one herding strategy was quite possibly in use. 


\section{Dogs in Northern Europe in the Bronze Age: mediating the real and the imaginary}

Although training and the innate skills of the dogs are vital to herding, equally important for success is the mutual socialisation of dogs and sheep. If the sheep are not familiar with dogs, they will not let themselves be fetched, driven or penned by a dog. A way of ensuring this socialization is to rear sheep and dogs in close proximity to each other. Research on early socialisation in different animal species has shown that there is a window of opportunity in which the young will establish a secondary social attachment to members of other species (the primary attachment is to the mother). The length of this time window varies from species to species. In lambs, such attachments can be formed possibly only during the first three days of life (Markowitz et al. I998), whereas puppies have a window of opportunity of 16 weeks (Bradshaw 20I I). Since lambs have a three-day window of opportunity for forming secondary social attachments with persons from other species, Bronze Age farmers might well have brought heavily pregnant ewes into the house to make sure the lambs were socialised with humans and sheepdogs from birth onwards.

I have previously argued that there are obvious advantages to keeping both sheep and dogs inside the house to facilitate habituation and socialisation from birth (Armstrong Oma 20I6, 20I 8a, 20I8b). In Northern Europe, the transition to sharing a roof with animals probably took place during Early Bronze Age period II (circa I500 BCE) when the architecture of the longhouse changed from a two-aisled structure, with a central line of roofbearing posts, to a three-aisled structure, with two parallel lines of posts (Armstrong Oma 2010, 2013a, 2013b, 2018a; Rasmussen I999; Tesch 1993). It is likely that the three-aisled houses accommodated both humans and domestic animals, each living in a different part of the house. From the perspective of habituation and socialisation, this way of living provides a beneficial framework for developing human-animal relationships. Research on dogs has demonstrated that socialisation and habituation to humans from birth and in the first period of life is crucial to develop positive feelings towards, and the ability to trust, humans. A British study demonstrated that $68 \%$ of dogs that frequently showed behaviour dominated by fear-aggression had been reared outdoors in a stable, in a yard or a shed, etc, and not inside houses together with humans (Appleby et al. 2002; Bradshaw 20I I; Solbakken 20IO). This early socialisation, in dogs from birth until I6 weeks, is key to developing the kind of healthy social security that is so vital to a strong working partnership (Bradshaw 20I I; Price 20I I; Westling 20I 4). Rock art and faunal remains demonstrate that Bronze Age farmers kept dogs, and may have been aware of the positive effect of rearing the puppies indoors. 
A close study of the portrayed positioning, bodily stance and interrelationships can give us clues about the artists' underlying ontological understanding of the world and the role and status of different beings within that world independent of the intention of the artist. From this perspective, rock art offers a rare glimpse into the lifeworlds of past people and into how they perceived their worlds and the beings that made up their world. Therefore, rock art is important for gaining a better understanding of past ontologies. In my reading, beings in Nordic Bronze Age rock art are depicted as sentient. Striking in this regard is that the dogs are fully immersed in the lifeworld and are portrayed in a variety of situations, beyond what I have discussed here (such as hunting, aggressive showing off and next to sun symbols and ships; see Gräslund 2004; Vevatne 1996) where they, by their agency, are co-creators of situations which they accentuate and help choreograph.

Although dogs and humans are frequently portrayed closely and in scenes where they seem to mirror and accentuate each other, they are not alone. The herding scenes demonstrate that an animal is not just an animal; rather, different animals are different kinds of being, and fulfill roles that are truly diverse. In this particular scenario, sheep are 'animals', shepherds are 'human' and dogs are somewhere in between. A good sheepdog handler will socialise the dog to be a free agent, and even though commands and communication are important factors in training, the most important factor is the development of trust and intuitive understanding among man, dog and sheep. The job performed by dogs in herding is of such importance to the shepherd that for most sheep farmers, dogs are indispensable. Sheep farmers will often describe the dogs as family members; they are allowed to live out their life on the farm, and are well cared for in their retirement (e.g. Kennard 2004, 2005).

The work that sheepdogs do is often conducted in dangerous, hilly, marginal landscapes. In parts of Scandinavia, the inaccessible topographies of mountain pastures create fringes in the landscape where it can be difficult and dangerous for humans to follow domestic animals, particularly sheep in transhumance figurations. In this situation, sheepdogs are vital to herding and their ontologically complex situation places them simultaneously on the fringe and casts them as mediators. When they herd sheep in topographically marginal landscapes away from humans they have to make individual decisions, and they mediate between shepherd and sheep and between accessible and inaccessible landscapes. They are the extended eyes, ears and voice of the shepherd - in this sense, they are one with the shepherd - and moreover, they act with surprising independence. Since sheepdogs are not human but act with human-like agency, they may be seen as hybrids.

The kind of hybridity suggested for dogs in the triad of herding might be complementary to, but not identical to, the hybridity suggested for art 
from the Bronze Age (Ahlqvist \& Vandkilde 20I8; Goldhahn 20I9) and the Iron Age (Hedeager 20II; Kristoffersen I995, 20I0) objects. Hybridity as an artistic imagining is frequently interpreted on the basis of hybrid beings that extend the bounds of species to incorporate elements from humans and different animal bodies, and is understood to express an ontology where boundaries between different types of bodies are not fixed but fluid, with porous bodies (Kristoffersen 1995; Ingold 20II). Often, this kind of hybridity is associated with animism (Ingold 2OII:II3) and more specifically with shamanism (Hedeager I999, 20I I; Price 2001, 2002), based on how shamans use animal parts and masks (e.g. Conneller 2004). The hybridity of sheepdogs is of a different nature as it is immersed in lived multispecies encounters and relationships that were deeply embedded in the fabric of society. Rock art scenes of herding reflect these lived relationships, and might be understood as complementary with the kind of hybrid beings identified by Ahlqvist and Vandkilde (20I8:I89), that they interpret within the scope of 'a universal cosmology of [Nordic Bronze Age] myths and narratives', albeit within a different sphere of society. Whereas images of hybrid beasts are an imagined merging of body, herding is a merging of minds and thus a blurring of the boundaries between these species (Keil 2015), but their bodies are their own. Possibly lived multispecies relationships as the one between shepherd and sheepdog enabled the idea of hybrid beings, not just by their choreographed herding with physical bodies but also in their role as an in-between role in society.

The herding scenes on rock art give an insight into some facets of the emergence of Bronze Age multispecies societies where sheep, dogs and humans lived in interdependence. Sheep are capable, through use of 'soft tools' such as the social transference of memory and traditions between generations, of creating and maintaining a society of their own (Mlekuz 20I2, 20I3). For Bronze Age farmers, sheep were producers of valuable assets (e.g. Årlin 1999) that the shepherd and the sheepdogs protect - wool and milk. New research on the provenance of wool textiles points to an extensive trade in wool in northern Europe in the Early Bronze Age (Frei et al. 20I5, 20I7; Randsborg 20II). In herding, a triad of sheep, sheepdogs and shepherds together perform a lifestyle that is necessary to ensure stable production and by extension a good life for all participants. The ontological status of each spring out of their own abilities, the process of herding, and the desired outcome - the product. In this society, dogs probably played many roles, as companions, hunters and herders. They occupied, in one sense, a fringe position by patrolling the boundaries and watching over both sheep and shepherds to keep them safe. They were a buffer between predators (for example wolves, their own ancestors) and prey - the sheep. In another sense they acted as a mediator between humans and the other animals as 
herding dogs that carried out the commands of the shepherd by physically moving in a complex choreography between, behind and around the sheep and the shepherd. On the job, the topographically diverse landscape of Scandinavia meant that the dogs must act independently and solve potentially life-threatening situations on the spot. Thus, the hybridity of the dogs rest in how they would balance at the interface between shepherd and sheep, by understanding the human intention underlying the herding scenario and developing complex and creative solutions according to their abilities to carry out the shepherd's goal. The human shepherds were providing for all, and did so by creating a choreography that framed a lifeworld in which these kinds of beings were intertwined and dependent upon each other.

\section{Acknowledgments}

I am indebted to the perceptive reviewers as well as to the editors for their insights and helpful comments. I wish to thank Katharina Becker for her help with putting the final version of this article together. Special thanks to Joanna Lawrence for pointing out the rock art panel at Himmelstalund Östra Eneby to me and to Astrid Johanne Nyland for allowing me to use a map drawn by her.

\section{References}

Ahlqvist, L. \& Vandkilde, H. 20I8. Hybrid Beasts of the Nordic Bronze Age. Danish Journal of Archaeology. Vol. 7(2) pp. I80-I94.

Appleby, D., Bradshaw, J.W.S. \& Casey, R.A. 2002. Relationship between Aggression and Avoidance behaviour by Dogs and their Experience in their First Six Months of Life. The Veterinary Record. Vol. I50(I4) pp. 434-438.

Argent, G. 20I 2. Toward a Privileging of the Nonverbal: Communication, Corporeal Sand Transcendence in Humans and Horses. In: Smith, J.A. \& Mitchell, R.W. (eds). Experiencing Animals: Encounters between Animal and Human Minds. Animal Studies Series, pp. I I I-I 28. New York: Columbia University Press.

Årlin, C. I999. Under samma tak: Om 'husstallets' uppkomst och betydelse under bronsåldern ur ett sydskandinaviskt perspektiv. In Olausson, M. (ed.). Spiralens öga: Tjugo artiklar kring aktuell bronsåldersforskning, pp. 29I-307. Avdelning för Arkeologiska Undersökningar Skrifter: Riksantikvarieämbetet.

Armstrong Oma, K. 20I0. Between Trust and Domination: Social Contracts between Humans and Animals. World Archaeology. Vol. 42(2) pp. I75-187.

Armstrong Oma, K. 20г3a. Human-Animal Meeting Points: Use of Sin the Household Arena in Past Societies. Society \& Animals Vol. 2 I(2) pp. I62-I77.

Armstrong Oma, K. 20I3b. Past and Present Farming: Changes in Terms of Engagement. In: Davies, M.I. \& Nkirote, F. (eds). Humans and the Environment: New Archaeological Perspectives for the 2 Ist Century, pp. I8I-I92. Oxford: Oxford University Press. 
Armstrong Oma, K. 20I6. Sheep, Dog and Man: Multi-species Becomings Leading to New Ways of Living in Early Bronze Age Longhouses on Jæren, Norway. In: Dommasnes, L.H., Hommedal, A.T. \& Gütschmidl, D. (eds). The Farm as a Social Arena, pp 23-5I. München: Waxmann Verlag.

Armstrong Oma, K. 2018a. The Sheep People: The Ontology of Making Lives, Building Homes and Forging Herds in Early Bronze Age Norway. Sheffield: Equinox Publishing.

Armstrong Oma, K. 20I8b. Making Space from the Position of Duty of Care: Early Bronze Age Human - Sheep entanglements in Norway. In: Pilaar Birch, S.E. (ed.). Multispecies Archaeology, pp. 214-229 London: Routledge.

Bekoff, M. 2002. Minding Animals: Awareness, Emotion and Heart. Oxford: Oxford University Press.

Benecke, N. 1994. Archäozoologische Studien zur Entwicklung der Haustierhaltung in Mitteleuropa und Südskandinavien von der Anfängen bis zum ausgehenden Mittelalter. Berlin: Akademie Verlag.

Bertilsson, U. 1994. Hällristningar och bygden. In: Bertilsson, U., Jansson, S. \& Lundberg, E.B. (eds). Hällristningar och hällmålningar i Sverige, pp. 82-I 20. Helsingborg: Forum.

Bradshaw, J. 20I I. In Defense of Dogs. London: Allen Lane.

Conneller, C. 2004. Becoming Deer: Corporeal Transformations at Star Carr. Archaeological Dialogues. Vol. II(I) pp. 37-56.

Cudworth, E. 20I I. Social Lives with Other Animals: Tales of Sex, Death and Love. Basingstoke: Palgrave Macmillan.

Deleuze, G. \& Guattari, F. 2004[1987]. A Thousand Plateaus: Capitalism and Schizophrenia. London: Continuum.

DeMello, M. 20I2. Animals and Society: An Introduction to Human-Animal Studies. New York: Columbia University Press.

Fredsjö, Å. I969. Hällristningar i västra Sverige. In: Fredsjö, Å., Janson, S. \& Moberg, C.A. (eds). Hällristningar i Sverige. Pp. 95-134: Stockholm: Forum.

Frei, K.M., Mannering, U., [...] Clarke, L. \& Frei, R. 2015. Tracing the Dynamic Life Story of a Bronze Age Female. Nature: Scientific Reports. Vol. 5(IO43I) pp. I-7.

Frei, K.M., Mannering, U., Vanden Berghe, I. \& Kristiansen, K. 20I 7. Bronze Age Wool: Provenance and Dye Investigations of Danish Textiles. Antiquity. Vol. 9I(357) pp. 640-654.

Game, A. 200I. Riding: Embodying the Centaur. Body \& Society. Vol. 7(4) pp. I-I 2.

Goldhahn, J. 2006. Hällbildsstudier i norra Europa: Trender och tradition under det nya millenniet. Gotarc serie C, Volume 64. Gothenburg: Arkeologiska skrifter.

Goldhahn, J. 20I9. Birds in the Bronze Age: A North European Perspective. Cambridge: Cambridge University Press.

Goldhahn, J., Fuglestvedt, I. \& Jones, A. (eds). 20Io. Changing Pictures: Rock Art Traditions and Visions in Northernmost Europe. Oxford: Oxbow Books.

Gräslund, A.-S. 2004. Dogs in Graves: A Question of Symbolism? In: Santilo Frizel, B. (ed.). PECUS. Man and Animal in Antiquity: Proceedings of the conference at the Swedish Institute in Rome, 2002. http://www.isvroma.it/public/pecus/graslund.pdf. [Accessed I5 October 2019]

Grimstvedt, M., Hertel-Aas, T. \& Jøssang, L.G. I996. Med sauen til heis. Nærbø: Jærmuseet.

Haraway, D. 1988. Situated Knowledges: The Science Question in Feminism and the Privilege of Partial Perspectives. Feminist Studies. Vol. I4(3) pp. 575-599. 
Haraway, D. 2008. When Species Meet. Minneapolis: University of Minnesota Press.

Harding, S. 1986. The Science Question in Feminism. London: Open University.

Hearne, V. 1987. Adam's Task: Calling Animals by Name. London: Heinemann.

Hedeager, L. I999. Skandinavisk dyreornamentik: Symbolsk repræsentasjon af en førkristen kosmologi. In: Fuglestvedt, I., Gansum, T. \& Opedal, A. (eds). Et hus med mange rom: Vennebok til Bjørn Mybre på 60-årsdagen, pp. 219-238. Stavanger: Arkeologisk museum i Stavanger.

Hedeager, L. 20I I. Iron Age Myth and Materiality: An Archaeology of Scandinavia AD 400-I000. London \& New York: Routledge.

Ingold, T. 20r r. Being Alive: Essays on Movement, Knowledge and Description. London $\&$ New York: Routledge.

Keil, P.G. 20I5. Human-Sheepdog Distributed Cognitive Systems: An Analysis of Interspecies Cognitive Scaffolding in a Sheepdog Trial. Journal of Cognition and Culture. Vol. I5 pp. 508-529.

Kennard, D. 2004. A Shepherd's Watch: Through the Seasons with One Man and His Dogs. London: Headline.

Kennard, D. 2005. The Dogs of Windcutter Down. London: Headline.

Kirksey, S.E. \& Helmreich, S. 20I0. The Emergence of Multispecies Ethnography. Cultural Anthropology. 25(4) pp. 545-576.

Kristoffersen, S. 1995. Transformation in Animal Art. Norwegian Archaeological Review Vol. 28 pp. 3-I5.

Kristoffersen, S. 20I0. Half Beast - Half Man: Hybrid Figures in Animal Art. World Archaeology. Vol. 42(2) pp. 26I-272.

Lia, Ø. 200I. Det rituelle rom: En fortolkende analyse av vikingtidens graver og landskap på Kaupang Unpublished MA thesis (hovedfag), Archaeology, Universitetet i Oslo.

Longton, T. \& Sykes, B. 1997. Training the Sheep Dog. Ramsbury, Wiltshire: Crowood Press.

Markowitz, T.M., Dally, M.R., Gursky, K. \& Price, E.O. 1998. Early Handling Increases Lamb Affinity for Humans. Animal Behaviour. 55(3) pp. 573-587.

Miklósi, Á., Kubinyi, E. [...] Virányi, Z. \& Csányi, V. 2003. A Simple Reason for a Big Difference: Wolves do not Look Back at Humans, but Dogs do. Current Biology Vol. I3 pp. 763-766.

Miklósi, Á. 2015. Dog Behaviour, Evolution, and Cognition. Oxford: Oxford University Press.

Mlekuz, D. 20I3. The Birth of the Herd. Society \& Animals. Vol. 21(2) pp. 150-I6I.

Nagel, T. 1986. The View from Nowhere. Oxford: Oxford University Press.

Nyegaard, G. 1996. Faunalevn fra bronzealder: En zooarkcologisk undersøgelse af sydskandinaviske boplatsfund. Copenhagen: Københavns Universitet.

Price, C. 20I I. Social Security. Your Dog. Vol. I2 pp. I2-I5.

Price, N. (ed). 200I. The Archaeology of Shamanism. London: Routledge

Price, N. 2002. The Viking Way: Religion and War in Late Iron Age Scandinavia. Uppsala: Uppsala University.

Pryor, F. 2006[1998]. Farmers in Prehistoric Britain. Stroud: Tempus.

Randsborg, K. 20Iг. Bronze Age Textiles: Men, Women and Wealth. London: Bristol Classical. 
Rasmussen, M. 1999. Livestock without Bones: The Long House as Contributor to the Interpretation of Livestock Management in the Southern Scandinavian Early Bronze Age. In: Fabeck, C. \& Ringtved, J. (eds). Settlement and Landscape, pp. 28I-290. Århus: Jutland Archaeological Society.

Scrimgeour, D. 2002. Talking Sheepdogs. Training Your Working Border Collie. Preston: The Good Life Press.

Solbakken, A.C. 20I0. Atferdskonsultasjoner over en tiårsperiode. Hundesport: Tidsskrift for norsk kennelklubb. Vol. I I I (9-I0) pp. 50-5I.

Sykes, B.I999. Understanding Border Collies. Ramsbury, Wiltshire: Crowood Press.

Sykes, B. 20I4. About the Breed: FOSTBC (Freedom of Spirit Trust for Border Collies), Bingley, UK. Online at: http://www.fostbc.org.uk/about-the-breed-I.asp [Accessed oI September 20I3]

Tesch, S. 1993. Houses, Farmsteads and Long Term Change: A Regional Study of Prehistoric Settlements in the Köpinge Area, in Scania, Southern Sweden. Uppsala: Uppsala University.

Thorsen, L.E. 200I. Hund! Fornuft og følelser. Oslo: Pax Forlag.

Toreld, A. \& Andersson, T. 20I7. Hällristningarna i Brastads socken. Vitlycke: Stiftelsen för dokumentation av Bohusläns hällristningar.

Ullén, I. I994. The Power of Case Studies: Interpretation of a Late-Bronze-Age Settlement in Central Sweden. Journal of European Archaeology. Vol. 2(2) pp. 249-262.

Ullén, I. I995a. Det goda exemplets makt: Närstudie av en bronsåldersbosättning i Uppland. In: Larsson, M. \& Toll, A. (eds). Sambällstruktur och förändring under bronsåldern: Rapport från ett bronsåldersseminarium på Norrköpings stadsmuseum, pp. 68-75. Arkeologiska undersökningar. Skrifter. Norrköping: Riksantikvarieämbetet.

Ullén, I. 1995b. Hushållet i Apalle under bronsåldern. Populär Arkeologi. Vol. I3(3) pp. 3 I-33.

Ullén, I. I996. Horse and Dog in the Swedish Bronze Age: A Close-up Study of the Relation of Horse and Dog to Man in the Bronze Age Settlement of Apalle. Archäologisches Korrespondenzblatt. Vol. 26 pp. I45-I66.

Ullén, I. I997a. Genomförande. In: Ullén, I. (ed.). Bronsåldersboplatsen vid Apalle i Uppland. Arkeologi på väg. Undersökningar för EI 8, pp. 9-2I. UV Uppsala Rapport. Arkeologiska Undersökningar. Uppsala: Riksantikvarieämbetet.

Ullén, I. I997b. Lager och hus. In: Ullén, I. (ed.). Bronsåldersboplatsen vid Apalle i Uppland. Arkeologi på väg: Undersökningar för EI 8, pp. 22-75. UV Uppsala Rapport. Arkeologiska Undersökningar. Uppsala: Riksantikvarieämbetet.

van Post, L. 1919. Ett par offerdammar från Skånes bronsålder. Rig. Vol. 2 pp. I60-I76.

von Rosen, B. I954. Hundbilder i de svenska hällristningarna. Hundar och hundsport. Vol. I954(7-8):I I 7-I22.

Vevatne, K. 1996. Ristningar i Etne: Ein analyse av tid og rom. Unpublished MA thesis (hovedfag), Archaeology, University of Bergen.

Westling, L. 20I4. The Zoosemiotics of Sheep Herding with Dogs. In: Tønnesen, M. \& Tüür, K. (eds). The Semiotics of Animal Representation, pp. 33-52. Amsterdam: Rodopi.

\section{PERSONAL COMMUNICATION}

Mlekuz, D. 20I2. Agencies of assemblages: Flocks, herds, households. Presentation at the annual meeting of the European Association of Archaeologists, Helsinki.

Toreld, A. 20I7. Stiftelsen för dokumentation av Bohusläns hällristningar. Personal conversation. 